\title{
INFORMAL SETTLEMENT AS A MODE OF PRODUCTION
}

\author{
Kim Dovey
}

\begin{abstract}
Informal settlements are neighbourhoods developed largely without state control that currently house over a billion people globally. Not to be confused with 'slums' or 'squatting', informality is the means through which a substantial portion of the global population have managed the transition from rural to urban life, transforming many cities across the Global South in the process. While some would hesitate to call this urban design or planning, it is where the action has been happening in urban development. With few exceptions, informal settlements will not, could not (?), and need not, be erased and replaced - the task is one of incremental redevelopment in situ. Yet traditional forms of urban design practice - focused on top-down regulation and the production of fixed designs and master plans - have proven inadequate to cope with the dynamism, complexity and adaptability of informal urbanism. This chapter outlines some ways of rethinking this issue through a theoretical framework of assemblage thinking. Informal and formal urbanism are not binary opposites but intersect to form complex alliances, contradictions and possibilities. Urban 'informality' can be understood as a mode of production that works both with and against the formal structures of the city. It works to produce new spatial structures and neighbourhood morphologies that need to be understood as assets held by the urban poor. And it works to produce particular kinds of place identity that impact on the image of the city and political struggles over the right to the city.
\end{abstract}

\section{INTRODUCTION}

Much has been made of the fact that most of the global population is now urban; cities are primary centres of economic opportunity and rural-to-urban migration continues unabated. It is not so often noted that most of this new urban population has been accommodated through the expansion of informal settlements in cities of the Global South. Under circumstances where the urban poor cannot secure access to formal housing, they settle wherever they can in the interstices and on the margins of the formal city. Such settlements are never informal in every way and are always enmeshed in complex relations with the formal structures of state planning. Depending on how such settlements are defined, they now house over a billion people. There is little prospect that anything more than a small percentage of such settlements will be demolished and replaced in a wholesale manner.

The disciplines of architecture, urban design and planning have traditionally focused on the formal order of the city - on formal protocols, procedures, plans and design outcomes through which the city is transformed and governed from top-down. The challenge of engagement with urban informality requires fundamentally different modes of thought and practice. While the construction, services and open space are often low quality (by formal design criteria), and occupation may be illegal, a key part of this challenge is to move beyond the labelling of 
informal settlements as 'slums' or 'squatter' settlements. The key argument of this chapter is that we need to understand urban informality as a mode of production of public space and a form of urban design. In general terms, informal settlement involves the occupation of otherwise unutilized land or space. This enables the production of affordable housing for a labour force that is otherwise unable to gain access to other urban housing markets. While informal settlements are marginalized in many ways, they are not marginal to the cities that have attracted them (Perlman 1976). The only realistic future is one of in situ upgrading, utilizing the very self-organizing forces that produce informal settlement in the first place.

Some important distinctions need to be made between 'informality' as a mode of production, the 'slum' as a particular urban condition, and 'squatting' as a particular kind of land tenure. A quick analysis of Google NGrams will show that the use of the terms 'slum' and 'squatter' have declined over recent decades while the use of 'informal settlement' has increased, often as a replacement. A 'slum' is defined by the UN in terms of a range of housing conditions, such as overcrowding and low-quality construction, generally accompanied by a lack of services, sanitation and open space (UN 2003). Yet 'slum' is a 'slur' word (like 'slob', 'slut', 'sly' and 'slump') with a history that hinders any accurate understanding of living conditions (Mayne 2017). As Mayne argues it evokes a stereotype that obscures a diversity of living conditions along with the energy and resilience of residents. It suggests a neighbourhood in a parasitic and illicit relationship with a host city; and the language of the slum is used to justify coercive action such as eviction and demolition. While there are good reasons to avoid the use of the term 'slum', 'informal settlement' is not a synonym for slum - informality is not a condition but a process.

The term 'squatter' also needs to be used carefully, less because it is derogatory than because it is rarely used accurately. 'Squatting' invokes a binary division between ownership and illegal occupation, yet most informal settlements fall into the ambiguous zone between these categories. Illegal subdivisions that take place on private land with the collusion of the owners are generally called 'pirate' developments, where residents 'own' the land informally. Squatters on public land generally acquire some form of de-facto tenure, if they can demonstrate a long period of occupation - the right known as 'squatter's rights' or 'adverse possession'.

Informal settlement then is a set of practices that need to be defined and understood separately from the 'slum' conditions and 'squatting' practices. However, I do not suggest or imply that informal settlements will be fine if simply left alone; many are unhealthy, overcrowded and poorly serviced. Many have insecure tenure and are vulnerable to forced displacement at the hands of a state determined to 'cleanse', modernise and formalize the city, often in league with the interests of capital (often global these days) to raise land values and claim key urban sites for redevelopment.

In contrast to the stereotypes of 'slums' and 'squatting,' I want to suggest that we understand informal settlement as a mode of production. Here, I return to the original definition of the informal sector as that part of economic production that falls outside the purview of the state and is not captured in measures such as GDP (Hart 1971). This definition includes everything from street trading to home cooked meals and is not defined by illegality. Informal settlement includes all forms of urban development that emerge outside the formal controls and regulations of the state in terms of land tenure, urban planning, design and construction. My focus here is limited to the self-organized production of urban space and excludes those forms of industrial production that can take place within informal settlements (Brugmann 2009). 
The phrase 'mode of production' has a particular history in Marxist thought, where it refers to the ways economic production is organized, incorporating both labour and the means of production (capital). The capitalist mode of production is where the means of production are owned by a ruling class; the current mode of neoliberal capitalism involves an alliance of the state with the interests of that class (Harvey 2007). For those such as Davis (2006: 17) the policies produced by neoliberal capitalism are "an inevitable recipe for the mass production of slums". While informal settlement is insinuated into this formal framework and can work in synergy, it involves a very different mode of organization - it is self-organized and the means of production are primarily controlled by residents. From a Marxist perspective, informality can be seen as a pre-capitalist mode of production that would inevitably and eventually be overwhelmed by and transformed into the capitalist system. What we find, however, is a complex co-dependency between formal and informal modes of production: organized capital clearly benefits from the low cost of labor that is enabled by informal settlements (Moser 1979: 1062). While politicians concerned with law and order may wish to erase such settlements, capital markets depend upon this cheap labor. Thus, informality is a mode of production that services the neoliberal state, even as it is targeted for eradication.

While it is the poorer cities of the Global South that have high levels of informal settlement, informality and formality have reciprocal relations in all economies and cities. We need to understand this relation not as a binary opposition but as an assemblage where informal and formal intersect to form complex alliances and possibilities. There is no simple continuum from formal city to informal city; rather the formal city becomes informalized as informal settlements become formalized. The primary contrast with the formal city is that informal settlements are self-organized rather than hierarchically organized, community-based and bottom-up rather than top-down.

\section{ASSEMBLAGE THINKING}

I have argued elsewhere that an effective theoretical framework for understanding informal settlements and urban design more generally, might be called a complex adaptive assemblage approach (Dovey 2012; 2016). This is an approach that seeks to join an assemblage approach from philosophy and social theory (Deleuze and Guattari 1988) with complex adaptive systems or resilience thinking (Walker and Salt 2006). A brief introduction to assemblage thinking will stress that an assemblage is a whole, whose properties emerge from interconnections, interactions, flows and synergies between its different parts (DeLanda 2006). The places, buildings, neighborhoods and identities that are the most visible parts of cities are the emergent effects of these processes. Assemblage is a way of understanding the city as produced by multiple desires and at multiple scales. It seeks to understand morphogenetic processes through which forms come into being - a philosophy of 'becoming' rather than a stable sense of 'being' or fixed identity. Any urban morphology embodies a set of immanent capacities that are linked to the possibilities of what it might become. Assemblage is thus a way of thinking about the city that connects research to design practice and urban imagination.

The concept of 'assemblage' is a translation of the French word 'agencement' which also means 'arrangement', 'alignment' and 'agency'. It has roots in the Foucauldian critique of power as embodied in micro-practices, as distributed and capillary rather than simply held by human agents. Assemblage thinking exploits this revolution in thinking about power for its emancipatory potential, as well as its critique of discipline and hierarchy, with a focus on power to (power as capacity) in addition to power over (power as control) (Lukes 1974). An axiom of assemblage theory is that power is distributed and embodied in material spatial arrangements. 
This is not a form of environmental determinism nor a displacement of human agency; it is a recognition that power as capacity is produced and practiced through the materiality and spatiality of the city.

The roots of assemblage thinking in urban design can be seen in the work of Jacobs (1961) and Alexander (1996) from the mid-twentieth century - the value of urban density, mix and walkable access networks, the seminal insight that 'a city is not a tree'. Assemblage thinking brings a focus on the key distinction between the horizontal rhizomic connectivity between parts and the vertical tree-like hierarchies that are used to organize the city. Jacobs also suggested that the then emerging work on complexity theory held potential for a better understanding of the synergistic effects of cities that cannot be reduced to cause-effect relations. This is the work that has evolved into complex adaptive systems, emergence theory and resilience thinking (Johnson 2001; Walker and Salt, 2006) with considerable influence in urban analysis. While I have reservations about any reduction of urban design to a science (Dovey and Pafka 2016), such work has many parallels with assemblage thinking. Assemblage thinking is anti-reductionist, resisting reduction to essence, text or materiality. An urban neighbourhood is neither a thing nor a collection of things. While people, buildings, practices, streets and so on all comprise the neighbourhood, it is the assembled connections between them and to other neighbourhoods that are crucial. An assemblage is dynamic - it is the flows of life, traffic, goods and money that give a neighbourhood its intensity and emergent sense of place identity. From an assemblage perspective the city is a dynamic field of differences - the identities of places, neighbourhoods and districts emerge from this field. Finally, it can be helpful to understand assemblage thinking as a conceptual toolkit - once the point is nailed home then the tool can disappear along with the jargon; theory is the means rather than the end of assemblage thinking. The point is not to make a theoretical point but to transform the ways we think about informal settlements.

\section{DIMENSIONS OF PRODUCTION}

As a mode of production, informal settlement can be understood through three primary dimensions focused on location, morphology and identity. Where and why do such settlements emerge, how are they formed, and what kinds of place identity are constructed? First, informal settlements produce a new kind of urban spatial structure -- organic, provisional, defiant -- using unutilized land to produce new synergies of functional mix within the wider metropolis, particularly walkable connections between housing and employment. Second, they produce the material infrastructure of buildings and street networks through informal development practices, that involve morphogenetic institutional (?) processes and new forms of urban governance. Finally, they produce particular forms of place identity within the larger urban imaginary. These are complex and interlaced issues. What follows is much more an agenda for research than a definitive account.

\section{Locating Informal Settlements}

First is the question of where and why informal settlement emerges. The simple answer is that they are where they need to be in order to gain access to the jobs and opportunities that the city offers. Any particular answer will be mediated by the availability of unutilized land together with topography, urban morphology, politics and history among other factors. I have previously suggested a typology that includes escarpments, waterfronts, infrastructure easements and accretions attached to the formal architecture of the city (Dovey and King 2011). Informal settlements emerge both in the interstices of the formal city and on its fringe. Interstitial 
encroachments are often juxtaposed or mixed with industry, retail, recreation and transport functions.

Figure 1 shows a mapping of urban informality in four cities drawn from on an earlier study that included 12 cities (Dovey and Kamalipour 2017). These are based on data from Google Earth and are limited to those morphologies that are visible and identifiable in aerial photographs; excluding those forms of informality that occur within the shell of existing buildings. This is of course a problematic task because there are different morphologies that can be identified as informal, and there is no simple continuum of greater or lesser degrees of informality. While a settlement may begin as entirely formal or informal, it often becomes mixed over time as formal buildings are added to an informal morphology, as informal buildings are formalized, and as informal buildings encroach within a formal street plan. There are also degrees of informality of the street and laneway networks as semi-organized encroachments produce semi-formal subdivisions. Fully informal networks also become formalized over time with laneways widened, straightened and so on. These maps are simplified and show urban areas divided into formal (dark grey), mixed (mid grey) and informal (light grey). This distinction is exemplified in Figure 2 and will be discussed in the following section.
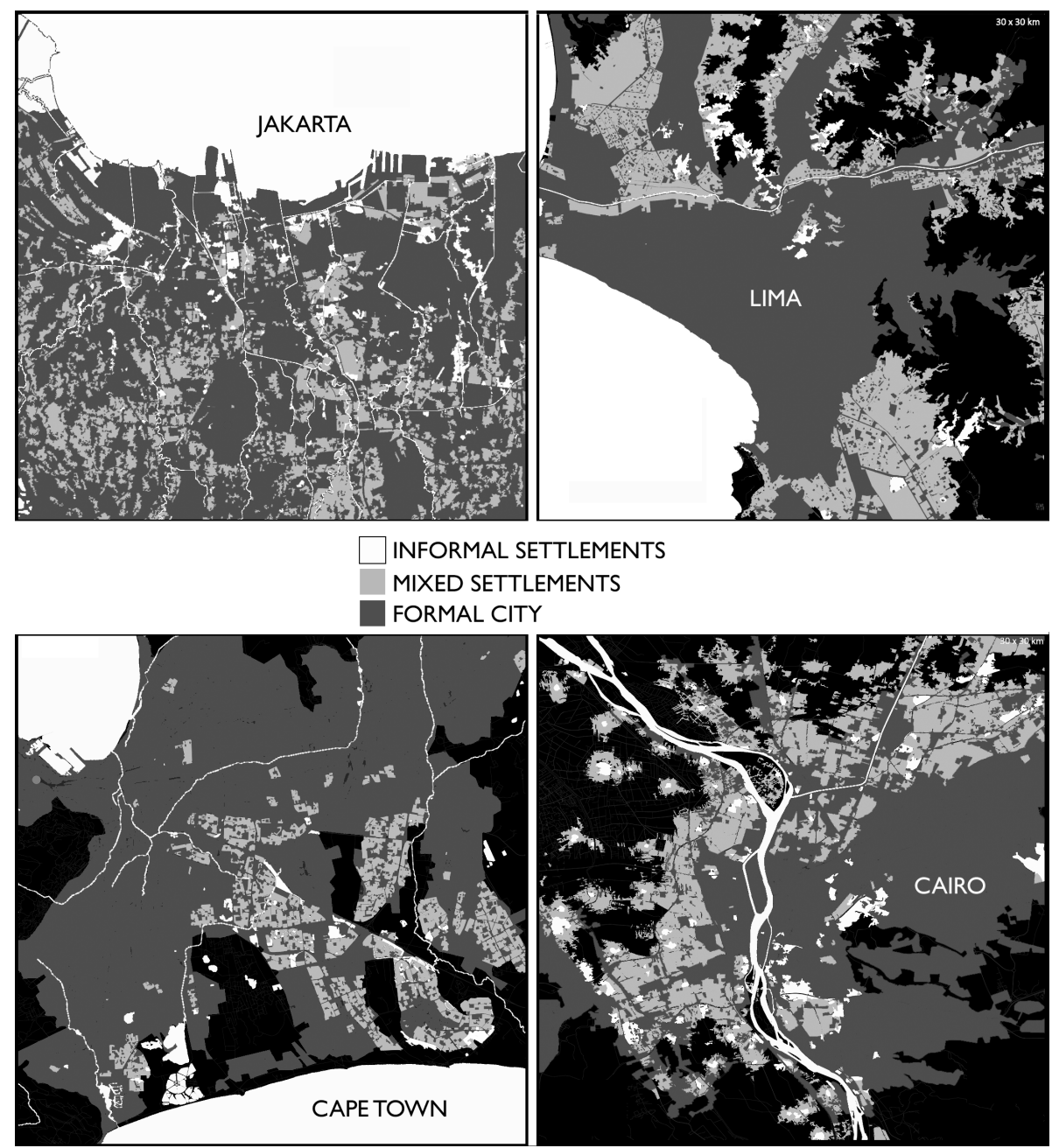

Figure 1: Metropolitan mapping of informal and mixed settlements in 4 cities (Source: Dovey and Kamalipour 2017)

The most obvious finding here is that the areas of mixed formal and informal settlements (mid grey) are far more pervasive in most cities than the stereotypic informal morphologies 
characterized by labyrinthine laneways (light grey). Another is that informal settlement patterns differ markedly from city to city, and are strongly mediated by topography and politics. Cities on the flat and wet coastal plains of Southeast Asia such as Manila, Bangkok and Jakarta show highly distributed patterns of small settlements and extensive areas of mixed informality. Jakarta is perhaps the most difficult of cities in which to draw any kind of line between the formal and the informal city (Simone 2014). Latin American cities such as Lima, Caracas, Rio de Janeiro and Medellin are strongly conditioned by encroachment onto steep escarpments. The legacy of apartheid in South Africa ensured that informal settlements were removed from the formal (white) city as is evident in the Cape Town settlements. Cairo is characterized by vast areas of semi-formal development on agricultural land, ironically produced in part by the state's plan to protect such land from development (Sims 2010).

There is much more that can be discussed and learned about the question of where informal settlements emerge, and while there are some common patterns, the answers will differ for each city. Such an understanding enables a diagnosis of how such settlements integrate with the formal city, or not, and how they might be better integrated. It enables a more transparent judgement of the conditions under which they might need to be relocated for resident safety or public benefit. And it facilitates a form of anticipatory design and planning - preventing encroachment, where it will be dangerous for residents or harmful to the city or environment; constructing key infrastructure in advance of settlement to render sites safe and well serviced (Gouvenour 2014).

\section{Morphology and Morphogenesis}

The second key dimension of informal settlement as a mode of production lies in the processes of morphogenesis, of how built form and urban design emerges. I have noted in the earlier section a key distinction in this regard between the more stereotypic informal settlements and the larger range of mixed morphologies as mapped in Figure 1 and illustrated in Figure 2. In a formal morphogenetic process, the street layouts with building plots always precede the construction of buildings - urban design precedes architecture. The informal morphogenetic process by contrast is relatively incremental and self-organized - the architecture and urban design co-evolve.

While there are variations of informal morphologies the most informal of settlements have a relatively similar morphogenic process that produces a relatively consistent pattern of access networks that is evident in many very different cities, climates and topographies (Figure 2a). Buildings are constructed incrementally, generally as a series of room-by-room accretions. The single room of no more than about 4-meter span is the most common spatial increment that may be extended horizontally or vertically to a limit of about four rooms. Incremental construction is geared to income flows, to capacities to store materials, and to the need for building materials to be transported and assembled by hand. Many houses are in a permanent state of becoming - a yard becomes a room as walls are extended and then roofed. A roof becomes a terrace when a stairway access is added, and a roof terrace becomes another room as walls are added and roofed. Smaller increments such as walls, roofs, balconies, verandahs and stairways are deployed in a myriad of ways to add to, divide or adapt different spaces over time. 
INFORMAL
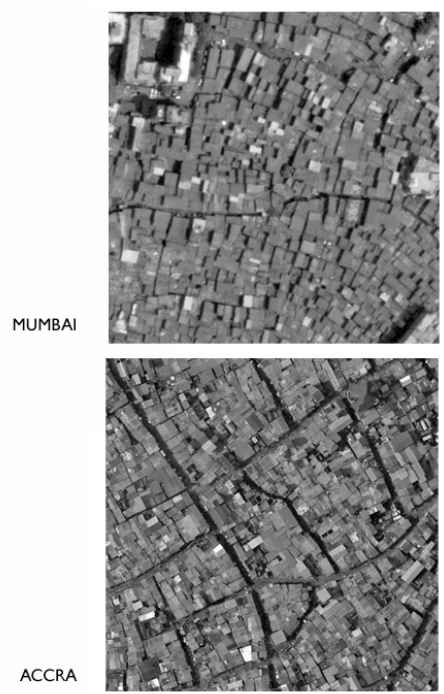

MANILA
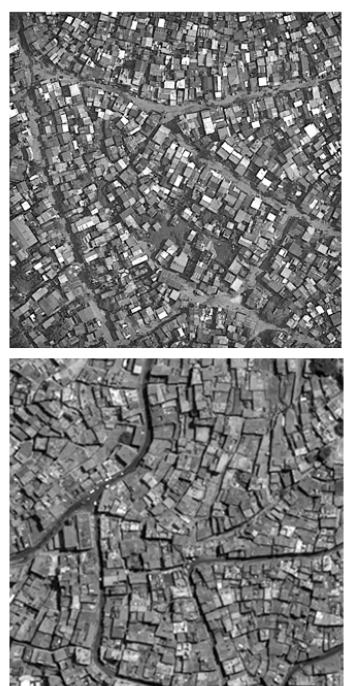

MIXED
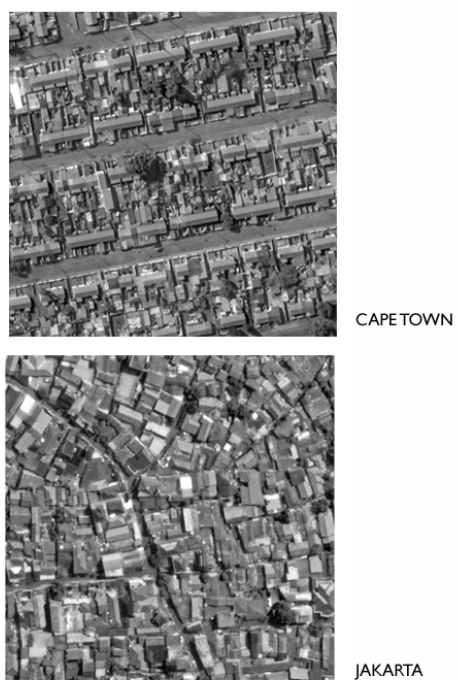

JAKARTA
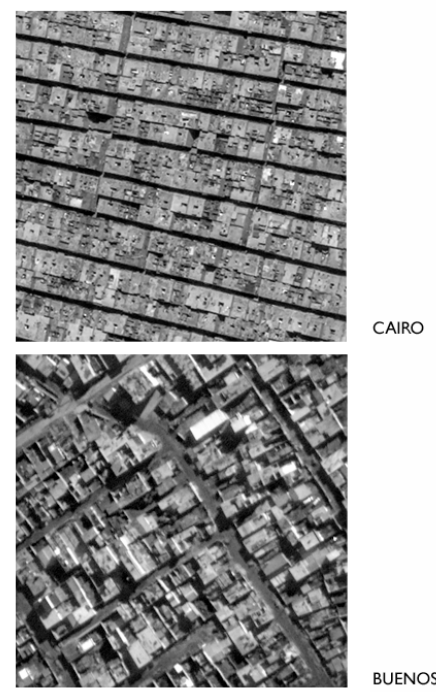

CAIRO

BUENOS AIRES

Figure 2: Informal and Mixed morphologies

(Sources: Google Earth/Digital globe)

At the same time a public space network emerges and co-evolves with the architecture.

Buildings may be constructed along existing pathways, but pathway networks also emerge incrementally between constructed buildings - a co-production of architecture and urban design. Some access ways will become more integrated with the network, and parts of houses fronting them may be converted to shops; others may be encroached and blocked but walkable access will be maintained to all buildings. Thus, informal settlements embody an emergent informal order or code of the kind that all cities need in order to work (Marshall 2009). Under conditions of poverty, however, such informal codes are often insufficient, and we see the result of a nasty version of the 'tragedy of the commons,' where incremental overdevelopment starves the public realm of space, light and air.

The morphogenesis of mixed areas is much more varied. The informalization of the formal city generally involves the incremental informal processes described above emerging within, around and on top of the architecture of the formal city. In the case of pirate development, the design of the street layout is often undertaken in anticipation of formal tenure and incorporation into the 
formal city. The urban design is driven in part by an attempt to shadow the forms of the formal city in terms of street widths and lots sizes. In other words, the codes that shape the formal city also shape the informal city in an informal manner. Figure 3 shows the informal morphogenesis as visible from Google earth data in four cities. The morphogenic patterns shift markedly from the highly informal in Accra and Manila to the semi-organized (or mixed) in Lima and Delhi.
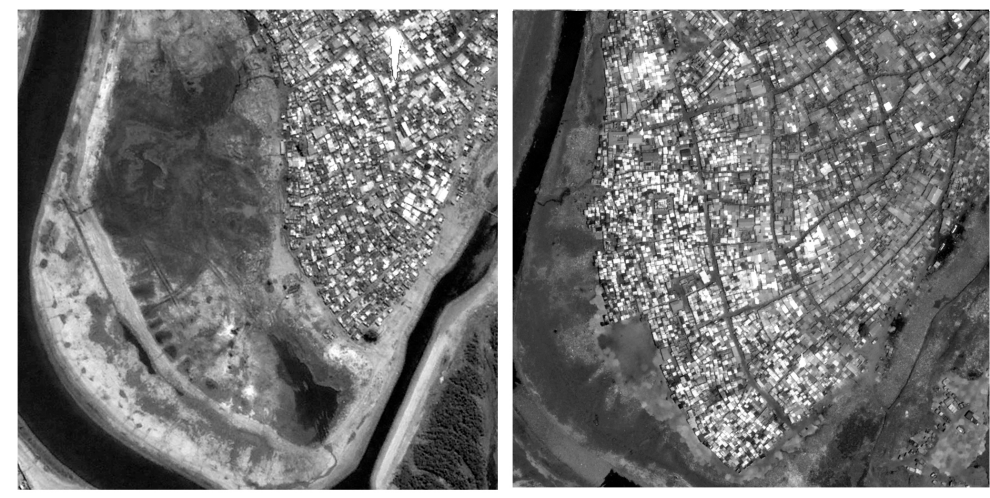

ACCRA

$2002>2014$
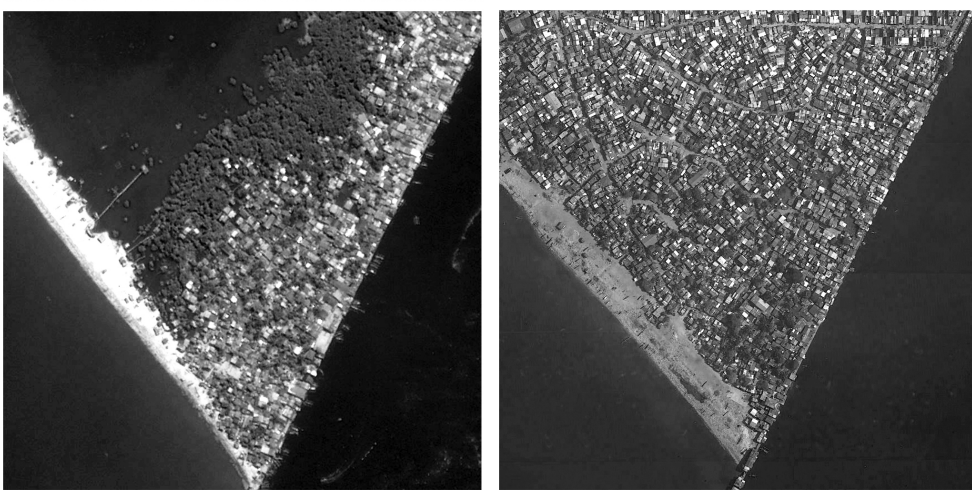

MANILA

$2001 .>2017$
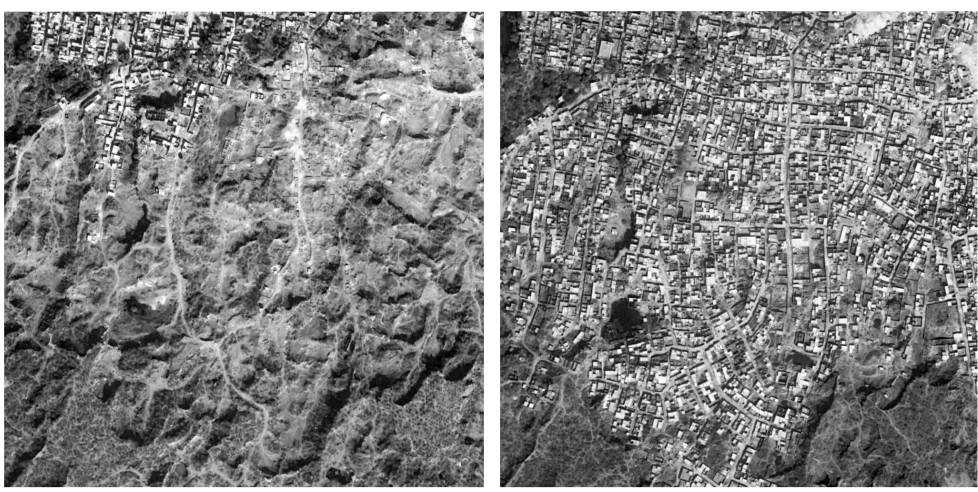

DELHI

$2008>2014$
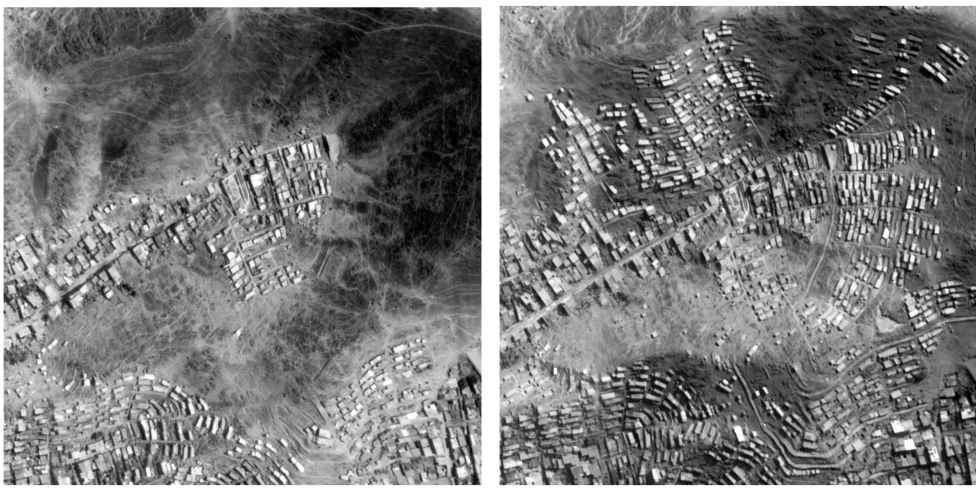

LIMA

$2014>2016$

Figure 3: Informal morphogenesis (Sources: Google Earth/ Digital Globe) 
The architecture can also be tenure driven since tenure often derives from duration of occupation. The buildings are often designed and built in a manner that will evade demolition by the state. Some areas are staked out and constructed overnight so that the settlement is makeshift but instant. Buildings may be upgraded to more permanent materials such as brick and concrete, which makes demolition less likely. In other contexts such upgrading may be the stimulus for demolition, so construction is hidden until complete.

Our understanding of informal morphogenesis remains very weak and this is a crucial field of research. Perhaps the best insight comes from the work of Hakim (2014) on the informal codes that traditionally produced Mediterranean urbanism and became formalized over time. He suggests that such codes embody proscriptions about encroaching on rights of way and limits to the height and extent of overhanging balconies and rooms; they generally respect existing usages and include the preservation of views and privacy. The urban design codes that prevail in informal settlements often fail to protect much more than minimal rights of access, yet in other cases encroachment is contained and open space is protected. The challenge of making and keeping informal settlements livable depends fundamentally on a better understanding of such processes. To understand such morphogenic processes provides insight into the emergence of informal urban design codes and the escalations of density into slum conditions. The challenge is to develop such existing codes into a more formal code, where the escalation of encroachment is contained or reversed. Any newly formalised codes that emerge need to sustain the productivity, amenity and sociality that is already embodied in the place.

\section{Image and Identity}

In her longitudinal study of favelas, Perlman (2010: 30) comments: "Perhaps the single persistent distinction between favelas and the rest of the city is the deeply rooted stigma that adheres to them and to those who reside in them... Even after the extensive... upgrading programs... there is little doubt as to where the asfalto (pavement) ends... The visual markers of each are unmistakable, whether viewed from above or on street level." Variations of this are true in all cities of the Global South - images of informality generally have negative symbolic capital for local populations. This is the third key dimension of how images of informality produce certain kinds of place identity that impact on the image of the city and political struggles over the right to the city. How are urban informal settlements 'read' within the discursive field of the city? How are these perceptions geared to political practices and policy development? Since the image and identity of informal settlements is generally seen as negative, their removal can be seen as a form of urban cleansing - rendering the city modern and formal. Images of law and order are strongly geared to political legitimacy. While it can seem odd to focus on design imagery when dealing with issues of poverty, this is a crucial and under-researched dimension of urban informality that plays a key role in political struggles over the right to the city.

It is, however, a most complex problem. Informal settlements are often hidden from the gaze of the formal city, do not appear on municipal maps, and Google Streetview rarely penetrates them. At times the state will act to hide informal settlements, generating a façade of law and order; residents may also pursue a deliberate blurring of boundaries between formal and informal, a form of urban camouflage. On the other hand there are many examples where arts projects are designed to produce a new identity and build local pride. Communities may be torn between the need to remain invisible in order to avoid eviction and the prospect of enhancing their visibility as a means to the same end. The rise of 'slum tourism' in some cities meets a global market which is also a complex mix of voyeurism, aesthetic attraction and a desire to learn more about such settlements (Dovey and King 2012). 


\section{INFORMAL SETTLEMENT AS EMBODIED AGENCY}

These three dimensions of informality as a mode of production are inextricably intermeshed in the production of urban neighbourhoods with particular metropolitan locations, morphologies and meanings. While this involves a focus away from the discourse of 'slums', there is no turning away from the pervasive conditions of poverty - informality is a means of both managing and potentially escaping poverty. As a mode of production, informal settlement is also a form of agency. Lister (2004) argues that the agency of people in poverty can be usefully understood in terms of four overlapping practices: 'getting by'; 'getting back'; 'getting out' and 'getting organized'. 'Getting by' is subsistence activity - basic shelter, food and sanitation. 'Getting back' involves transgression of the formal codes of state control and informality as a form of everyday resistance. 'Getting out' of poverty is more strategic - improving or extending the house, renting out a room, getting a job, educating children. 'Getting organized' encompasses strategic and often political activities by community-based organizations. These categories are not mutually exclusive nor all encompassing, but this is a useful framework for understanding urban informality as a means of managing and escaping poverty.

These forms of agency are the 'weapons of the weak' as Scott (1985) puts it. This power is not simply held by residents but is embodied in the socio-spatial assemblage of the informal settlement and its many intersections with the formal city. Informal settlements can be understood as an assemblage of assets or capacities that enable residents to live a life, acquire an income, raise their children and build prospects for a better future. The more we understand what these assets are and the ways they are geared to the urban morphology and spatiality, the more likely it is that policy and practice will be effective.

A first cluster of assets involves those embodied in the house and land. Informal settlements are geared to job markets and to the larger urban context - walkable access to local employment and public transport networks are crucial assets. Most informal settlements hold some form of ambiguous or de facto land tenure, often recognized by the state based on length of occupation or payment of land tax. Whether formally recognized as land tenure or not, the occupation of land is an asset that increases over time through the right of adverse possession. Regardless of land tenure, the buildings constructed within an informal settlement are owned by those who constructed, inherited or bought them. The house often represents a long-term investment over more than one generation and the most substantial asset held by that household. The assets of house, land and location are geared to each other because informal tenure is held by the house, and the value of the land lies in its location.

A second cluster of assets is embodied in the particular morphologies of informal settlements through their potentials for adaptation. The incremental construction process enables rooms to be added at a rate commensurate with income flows. Residents hold 'air rights' to the space above the last room they have built, and this represents a prospect for additional space and possible rental income. Direct interface with a laneway network enables public space to be used as an extension of the private realm - relieving internal crowding, creating opportunity for socialization, childcare and domestic production. It can be adapted to various kinds of production and exchange, or external access to an extra room and rental income. These adaptive capacities are embodied within the informal morphology and are generally extinguished in any replacement housing projects. 
These spatial and material assets need to be understood as crucial to any decisions residents might make about 'upgrading' programs, which may require various trade-offs: Will they have access to the city, or direct access to public space? Will they be asked to convert from ownership to rental? Will they lose rental income? Can they build an extra room or open a shop? If any of these assets are taken away without equivalent benefit, then it will not be in the residents' interest to support such a program. Of course they may negotiate a deal where they accept compensation and relocation but then sublet their allocated apartment and move back closer to employment - to another informal settlement where the cycle repeat, a common phenomenon in the history of managing informal settlements..

\section{DISCUSSION}

This then is the knowledge base for any attempt to understand or transform informal settlements from an urban design perspective. First, we need to know why they are located where they are, and how this location enables access to jobs via public or walkable transport. For many settlements on urban fringes and in inaccessible locations, better access is the key to upgrading. Some settlements are unsustainable in current locations due to unstable conditions that cannot be mitigated. Under freeways, lining railway lines and sidewalks is no place to live, but any replacement housing must be located with similar access to employment, if the displacement is not to stimulate more informal encroachment. Second, any attempt by local authorities to improve their living conditions should be based on an understanding of the highly adaptive morphogenetic processes through which settlements are developed - informal adaptations and encroachments are unlikely to cease. The design of replacement housing must consider the value of the street/lane interface and must be adaptable, to incremental change and expansion even when designed at higher densities. Residents will rightly resist any form of relocation and reconstruction that does not acknowledge and at least match the current range of assets and the agencies embodied in the informal morphology. Third, any attempt at improvement needs to understand the socio-political impact of the image of the settlement: areas of visibility from the surrounding neighbourhood, access routes through it, the meanings attached and the prospects for change.

There are many good thinkers who suggest or imply that the retention and transformation of informal settlements is pointless, that the key task is one of overturning the global conditions of economic inequality and neoliberal capitalism that produces it. In his seminal book Davis (2006: Ch.4) spends a chapter arguing against what he terms 'self-help' schemes that often fail or exacerbate the problem. He argues that funds leak through corruption; that owner-built housing is shoddy; that incremental construction is inefficient; and that NGOs can co-opt the interests of residents to their own. These views, however, reflect a blindness to how urban informality works as a mode of production. Informal construction produces affordable housing at a fraction of the cost per square metre compared to the formal production process (Sims 2010). Corruption is of far less consequence than in formal construction processes. While construction standards are often initially shoddy, in most settlements the majority of buildings can be effectively upgraded in situ rather than replaced.

Davis (2006) also suggests that self-help programmes divert the urban poor from political struggle. Yet informal settlement is already a form of political insurgency that produces new forms of urban governance and deep democracy. The political struggle of informal settlement residents to remain in place and to upgrade their neighbourhoods is being won in many parts of the world. While coercive eviction remains common, forced eviction and demolition of 
informal settlements has become the exception rather than the rule. This struggle is not only over eviction, but over control of the settlements themselves; in many informal settlements 'informal' development is organized, and profit is extracted by gangs or slumlords. Some house clusters of industrial production in sweatshop conditions that again demonstrate deep affinities between the deregulatory regimes of neoliberal capitalism and informality. These local and global struggles are interconnected - there is no need to choose between support for upgrading practices and for global political change.

\section{CONCLUSION}

The goal of this chapter has been to sketch the knowledge base for any kind of urban design intervention in informal settlements. There are many examples of good practice in this regard, but they do not lend themselves to the kind of 'best practice' discourse that dominates much of the urban design thinking - best practices are local responses and not global formulae. Much current thinking and practice remains locked into a formalization framework, wherein knowledge developed within the formal city is applied, and the settlement becomes formalized top-down. The task, however, is not simply to replace top-down with bottom-up, but to understand how formal and informal intersect. This often entails dealing with a double-logic, where the adaptive powers of informality are harnessed, while services, construction standards, and public space are improved.

Assemblage thinking is a useful framework for understanding these relations between formal and informal, and for understanding incremental change and emergent identities. It can help in reminding us that informal settlements are always already in a process of upgrading and formalization. 'Assemblage' is at once verb and noun, suggesting both dynamic process and formal configuration. It shares this condition with the term 'settlement' as both a process of becoming settled and a socio-spatial outcome. The take home message of this chapter is not to make a theoretical point but to understand how urban informality works to produce affordable housing for billions of people throughout cities of the Global South. In this regard, we have barely scratched the surface.

\section{REFERENCES}

Alexander, C. (1996). "A City is not a Tree", in R. LeGates, and F. Stout (eds) The City Reader. London, Routledge, 118-131 (originally published 1965).

Brugmann, J. (2009). Welcome to the Urban Revolution. London: Bloomsbury.

Davis, M. (2006). Planet of Slums. London: Verso.

DeLanda, M. (2006). A New Philosophy of Society. New York: Continuum.

Deleuze, G. and Guattari, F. (1988). A Thousand Plateaus. London: Athlone.

Dovey, K. (2016). Urban Design Thinking: A Conceptual Toolkit. London: Bloomsbury.

Dovey, K. (2012). "Informal Settlement and Complex Adaptive Assemblage", International Development Planning Review, 34 (3) 371-90.

Dovey, K. and Kamalipour, H. (2017). "Informal/Formal Morphologies", in: K.Dovey, et al (eds) Mapping Urbanities. New York: Routledge.

Dovey, K. and King, R. (2012). "Informal Urbanism and the Taste for Slums", Tourism Geographies, 14(2) 275-93.

Dovey, K. and King, R. (2011). "Forms of Informality", Built Environment, 37(1) 11-29.

Dovey, K. and Pafka, E. (2016). "The Science of Urban Design?" Urban Design International, 21(1) 1-10.

Gouverneur, D. (2015). Planning and Design for Future Informal Cities. New York: Routledge. Hakim, B. (2014). Mediterranean Urbanism. Dordrecht: Springer. 
Hart, K. (1973). "Informal income opportunities and urban employment in Ghana", Journal of Modern African Studies, 11, 61-89.

Harvey, D. (2007). A Brief History of Neoliberalism. Oxford: Oxford University Press.

Jacobs, J. (1961). The Death and Life of Great American Cities. Harmondsworth, Penguin.

Johnson, S. (2001). Emergence. London: Penguin.

Lister, R. (2004). Poverty. Cambridge: Polity.

Lukes, S. (1974). Power. London: MacMillan.

Marshall, S. (2009). Cities, Design and Evolution. London: Routledge.

Mayne, A. (2017). Slums: The History of a Global Injustice. London: Reaktion.

Moser, C. (1979). "Informal Sector or Petty Commodity Production", In R. Bromley (Ed.), The Urban Informal Sector. Oxford: Pergamon, pp.1041-1064.

Perlman, J. (1976). The Myth of Marginality. Berkeley: UC Press.

Perlman, J. (2010). Favela. Oxford: Oxford UP.

Scott, J. (1987). Weapons of the Weak. New Haven: Yale UP.

Simone, A. (2014). Jakarta: Drawing the City Near. Minneapolis: Minnesota UP.

Sims, D. (2010). Understanding Cairo: The logic of a city out of control. New York: American University in Cairo Press.

Turner, J. (1976). Housing by People. London: Marion Boyars.

UN-Habitat (2006). The State of The World's Cities. London: Earthscan.

Walker B. and Salt, D. (2006). Resilience Thinking. Washington: Island Press.

\section{Further Reading}

Sims, D. (2010). Understanding Cairo: The logic of a city out of control. New York: American University in Cairo Press. Perhaps the best account of both morphologies and processes of informal development within a single city.

Hakim, B. (2014). Mediterranean Urbanism. Dordrecht: Springer. An investigation of the informal and formal urban design codes that produce traditional Mediterranean cities.

Dovey, K. and Kamalipour, H. (2017). "Informal/Formal Morphologies", in: K.Dovey, et al (eds) Mapping Urbanities. New York: Routledge. Proposes a typology of informal/formal morphologies that is mapped across 12 cities of the global south.

Dovey, K. (2016). Urban Design Thinking: A Conceptual Toolkit. London: Bloomsbury. 


\section{University Library}

\section{- M M I N E R VA A gateway to Melbourne's research publications}

Minerva Access is the Institutional Repository of The University of Melbourne

Author/s:

Dovey, $\mathrm{K}$

Title:

Informal Settlement as a Mode of Production

Date:

2019-05-29

Citation:

Dovey, K. (2019). Informal Settlement as a Mode of Production. Loukaitou-Sideris, A (Ed.). Bannerjee, T (Ed.). The New Companion to Urban Design, (1), pp.139-151. Routledge.

Persistent Link:

http://hdl.handle.net/11343/241542 